\title{
MINORITY LANGUAGES UNDER NAZI OCCUPATION
}

\author{
CAMIEL HAMANS
}

\begin{abstract}
This paper discusses the special interest the Third Reich ideologues had for Germanic minority languages. In particular, the situation in Friesland, Flanders and Brittany is addressed. Moreover, it is made clear how German linguists from that period tried to annex Wallonia as an original Germanic area. Finally, the consequences of this cooperation with the Nazi occupier for the post-war discussions about these minority languages are briefly indicated.
\end{abstract}

Key words: language diversity, minority language, endangered language, indigenous communities, Nazi occupation

\section{Introduction}

The acceptance of language diversity, or at least the tolerance for it, is usually associated with the last quarter of the $20^{\text {th }}$ century, the time when the Council of Europe initiated the Charter for Regional and Minority Languages (1992) and when the Comite International Permanent des Linguistes, the global organisation for linguists, accepted the documentation and promotion of 'endangered languages' as it main priority at the $14^{\text {th }}$ International Congress of Linguists (Berlin 1987). Four years later CIPL's president and secretary - general edited the first overview of Endangered Languages (Robins and Uhlenbeck, 1991) which was the same year in which the Linguistic Society of America began to focus of language endangerment. On the occasion of the celebration of the $500^{\text {th }}$ anniversary of the 'discovery' of America Colette Craig and Ken Hale the first LSA Panel on language endangerment. At the same time this panel was an echo of the protests of the alliance of indigenous 
communities. In 1992 and 1993 the prestigious linguistic journal Language (Vol. 68, 1,4 and 69,3 ) started a debate about the role of linguistics in situations of language endangerment. Participants in the discussion were among others Craig and Hale, and especially Peter Ladefoged and Nancy C. Dorian.

Although attention to minority languages only became structural at this time, it is certainly not the first and only period in history in which both political authorities and linguists expressed an interest in minority languages. For example, the German Nazi regime was very interested in the languages of some minorities in neighboring countries for political and ideological reasons. In this contribution the Nazi involvement in some languages of minorities will be discussed.

The German national-socialists, Nazi's, had a special interest in race, as is well known. However, when it came to the relationship between language and race in the countries they occupied, this interest led to different approaches. Here only a few linguistic minorities in Western-Europe will be discussed. The national-socialist regime had a completely different view of minorities in the eastern, newly acquired territories. The German speaking minorities in this part of Europe were brought Heim ins Reich 'back home to the [Third] Reich'. Yiddish speaking minorities were prosecuted and almost completely killed, just as all other Jews. The Slavs were also considered Untermenschen 'sub-humans' (Longerich, 2010: 241). Therefore, there was no need to defend or promote their languages. ${ }^{1}$

In the case of Germanic minority languages such as Frisian and Flemish they stressed the family relation and supported the autonomy movements. In the case of a non-Germanic minority language such as Breton they stressed the differences between the national language French and the minority language, supported the rights of this minority and its language and tried to weaken the power of the central French

\footnotetext{
${ }^{1}$ The Nazis used a classification Volksliste 'People's List' of different groups in Eastern Europe. Next to people who considered themselves as Germans, although they had a different nationality, the so called Volksdeutsche 'ethnically Germans', there was a category Eingedeutsche 'voluntarily germanised', people who were fit for germanisation because of the special relation of their group with Germany or the Germanic family. The Kashubians (North-West Poland), Mazurians (East Prussia, North-East Poland), and Silesians (South-East Poland) were considered eingedeutscht. These groups each speak a different West Slavic language which all three underwent considerable German influence through contact with German or through deliberate attempts at Germanization. Although the Germans treated the Kashubians, Mazurians and Silesians differently and better than the Poles, this did not mean that their culture and minority languages were recognized. On the contrary, the languages and cultures were banned. The people were supposed to germanize as quickly as possible (Burleigh and Wippermann, 1991: 131-132). The Nazi policy towards the Sorbs, a West Slavic ethnic group living in Saxony (Germany), was 'the negative mirror image of policy towards the Kashubians'. Among protestant Sorbs the sympathy for the national socialist ideology was rather high. "Henceforth, Sorbian separatist tendencies were condemned, but at least officially the Sorbian language and customs were to be left to die out of their own accord. Sorbian nationalists responded with a superficial, tactically-motivated espousal of some aspects of Nazi 'Blood and Soil' ideology (...)” (Burleigh and Wippermann, 1991: 132).
} 
government and nation in this way. The third option was an attempt to prove that a minority such as the Walloon speaking population of Belgium actually was of Germanic origin and was only Frenchified in the course of the history.

\section{Frisian}

In the Dutch province of Friesland, a very small political party was founded with a typical racist 'volks' 'folk' program in 1938. No wonder that after May 1940 the German occupying forces tried to find support in this circle. The aim of the Nazi's was to reintegrate nine million related but alienated Dutch people into the community of German people. Within the Dutch people, the Frisians, as the most Germanic tribe, took a special place according to the Germans. 'Free and Frisians belong together according to our imagination",' became the slogan. "In our opinion, the free Frisian is part of the characteristic image of a people-based freedom" (Frieswijk, 1998: 270). The Frisian was a prototypical Germanic hero in the eyes of the Nazis.

Immediately after the Dutch defeat in 1940, German officers came to Friesland to promote cooperation. Some of these army officers were linguists or historians belonging to one of the Frisian speaking minorities in Germany, and who had been in contact with Frisian scholars before. The German authorities were generous in providing subsidies. To coordinate the activities of the different institutions for the promotion of Frisian, a triumvirate was created with representatives from the different branches of the Frisian nationalistic movement. One of the members was an active national-socialist. However, he appeared to be such a difficult person that he was fired soon. No successor was found or appointed. That is why and how the Frisian movement succeeded to keep a distance from the Germans.

Contrary to this observation is the fact that the SS-think tank Ahnenerbe 3 'ancestral heritage' managed to start its own but small working group in Friesland. However, the German authorities felt compelled to dissolve the group in 1944 for fear of separatism (Frieswijk, 1998: 270). The German occupying authorities were the first to support Frisian literature and theatre financially, which they did generously. That is why among authors and (amateur) actors there were more collaborators than in the rest of the Frisian population (Zondergeld, 1981). To summarize, it can be concluded that the influence of national socialist ideas on the Frisian Movement has been limited, despite the attempts to do so were undertaken or supported from the central government in Berlin.

\footnotetext{
2 "Frei und Friese gehören für unsere Vorstellung zusammen. Er erscheint uns als das Characterbild völkischer Freiheit."

${ }^{3}$ For more details about this think tank, see section 5 .
} 
In fact, the collaboration of some of the leaders of the Frisian Movement did not do much harm to the Frisian cause. Shortly after the Second World War, the Frisian case reached a provisional high point with the riots of Kneppelfreed, Truncheon Friday, when the Frisian editor, poet and social-democratic politician Fedde Schurer was convicted of insult. It became the starting point for a long-term, peaceful and ultimately successful action for the recognition of Frisian, which ended with formally establishing the bilingual character of the province in $1985 .^{4}$

\section{Flanders}

In Flanders the situation was completely different. Flanders, the Dutch speaking part of Belgium, was an economically backward area. All the industrial activities took place in the French speaking part. Moreover, French was seen as a superior language by the people in power. There was serious discrimination of Flemish and Flemish speakers in Belgium.

The striking similarities between the vernaculars of Flanders and the Low German language led to first contacts between language activists from Flanders and North Germany in the last decades of end of the $19^{\text {th }}$ century. However, it was only during the First World War and the occupation of Belgium by the Germans that a specific interest arose at both sides. The Flemish saw an opportunity to break the hegemony of the French speaking part of Belgium, whereas the Germans thought to make friends by supporting the Flemish case. Moreover, at both sides there were people who saw the struggle for Flemish as a fight for a common Germanic goal. The well know Flemish activist August Borms, (1878-1946), who collaborated with the Germans during both World War I and II and who therefore was executed in 1946, explicitly claimed that fighting for Flemish was fighting for a common Germanic case (Dolderer, 2003: 11). In Low German periodicals of the post-World War I period Flanders was regularly called 'the Germanic outpost in the West' (Dolderer, 2003: 14).

The German occupying authorities developed a so called Flamenpolitik 'Flemish policy', that was intended to convince the Flemish to consider the Germans not as their occupiers but as their liberators or at least as their allies in their struggle with the French oppressors. One of the measures taken by the German authorities was the long pursued Dutchification of the Ghent University in 1916. All education at this university, mainly attended by Flemish people, was given in French until that time. After the German defeat, the education at Ghent University became exclusively French again. One had to wait till 1930 till the education and the administration became Dutch. (De Weever, 1994: 19-32).

\footnotetext{
${ }^{4}$ For more details about the Frisian language fight and Dutch language policy in general, see Hamans (2016).
} 
During the Second World War the German troops occupied Belgium again. The national-socialist Third Reich resumed the Flamenpolitik of the First World War period and granted the Flemish a privileged position over the Latin Walloons. German-minded Flemings were given important positions, more than 100.000 Flemish prisoners of war were released, and Hitler even promised autonomy for Flanders in July 1940, which was never realized. Because of all these Flemish-friendly measures quite some Flemish activists collaborated with the Nazis and even joint their battles at the eastern front. ${ }^{5}$ The sympathy of large groups of Flamingants ${ }^{6}$ for the national socialist cause led to a bad odor in the post-war pursuit for more rights for Dutch in Belgium. In fact, the association of the Flemish movement with the German occupiers during the two world wars has done more harm than good to the emancipation of Dutch in Belgium.

As a result, the breakthrough in the Flemish Language Fight only came in 1968, when Flemish students demanded that the Catholic University of Leuven, located in the Dutch-speaking part, but which was nevertheless governed by monolingual speakers of French, would from now on be exclusively Flemish. This was the start of a complex process of recognizing the rights of Flemish speakers, which ultimately led to changes in the Belgian constitution and finally the federalization of Belgium, in which the French-speaking part of Wallonia and Flanders are largely autonomous.

\section{Wallonia}

Although the official Nazi point of view was that the French speaking part of Belgium, Wallonia, was populated by decadent and weak Latin Walloons, this did not prevent German scholars to defend other positions. A group of historians working at the University of Bonn, consisting of Herman Aubin (1885-1969), his successor Franz Steinbach (1895-1964) and Franz Petri (1903-1993), the successor of Steinbach at the Institut für geschichtliche Landeskunde, 'Institute of historical regional studies', developed a discipline called Kulturraumforschung 'cultural area studies'. This research program started in the 1930's. In 1937 Petri published his seminal book Germanische Volkserbe in Wallonien und Frankreich. Die fränkische Landnahme in Nordfrankreich und den Niederlanden und die Bildung der westlichten Sprachgrenzen 'Germanic folk heritage in Wallonia and Nord France.

\footnotetext{
${ }^{5}$ For a more detailed history of the relation between Flemish nationalism and the Third Reich see De Jonghe (1972) and De Weever (1994).

${ }^{6}$ Flamingant is the name for activists who aimed at equal rights for Flemish. Although one speaks about the Flemish movement, the standard or national language they aimed at was Dutch. There was no Flemish standard language. In the last thirty years, Dutch has become a pluricentric language. The differences between Netherlandic Dutch and Flemish Dutch are growing. However, officially it is still the same Dutch that is the standard language in Flanders as well as in the Netherlands.
} 
The Frankish conquest in France and the Netherlands and the formation of the western language linguistic borders'.

On the basis of the results of archaeological research, toponymical studies and analysis of the lexicon of agriculture, household, rural life, warfare and craft, these Bonn scholars came to the conclusion that the Romance-Germanic language border, which now runs through Belgium, should originally be situated much more to the South, maybe so far as to the Loire. In other terms this entire region, that had been populated by the Franks, was, in fact, Germanic territory, a claim which was so welcome to the national-socialist regime that Hitler $^{7}$ accepted it in early 1943 (Wood, 2013: 245-266). However, it was too late in the war to be able to introduce a new policy and to achieve success.

By the way, the type of research done by the Bonn school is not specifically German or national socialist. In the years after 1945 Polish historians and linguists under the leadership of Zygmunt Wojciechowski ${ }^{8}$ and his Instytut Zachodni, 'Western Institute', did similar research in order to prove that the newly acquired or recovered regions of West Poland originally were Slavic.

\section{Brittany}

The German fascination for the Celtic past and language goes back to Goethe and Herder and their mutual interest in the Songs of Ossian. For instance, in 1771 Goethe sent a letter to Herder in which he translated 38 lines of a Gaelic text by Macpherson, the author of Ossian. ${ }^{9}$ The interest in Celtic culture, literature and language was usually mixed with admiration for Celtic heroism and martyrdom. Pioneers in Celtic studies easily became politically involved in this way: Rudolf Thurneysen (1857-1940), the author of the standard grammar of Old Irish, expressed his solidarity with the Irish freedom fighters who launched the Easter Rising of 1916 and called them heroes. Julius Pokorny (1887-1970), also a great Indo-Europeanist and Celticist, compared the Irish Easter Rising with the German freedom struggle against Napoleon Bonaparte (Luyken, 1996). Leo Weisgerber (1899-1985), the most prominent pupil of Thurneysen and still well respected as a linguist in Germany, 'later proudly described how [German] Celtology had undermined the outside forts of the English and French hereditary enemies':

\footnotetext{
${ }^{7}$ The leader of the Walloon fascist Rex movement, Léon Degrelle, called the Walloons as 'a Germanic tribe which was gallicized due to historical misfortune'. Hitler finally accepted this view in 1943 (Conway, 1994: 206-207).

${ }^{8}$ Cf. https://en.wikipedia.org/wiki/Zygmunt_Wojciechowski

${ }^{9}$ For more details about Goethe's interest in the work of Macpherson and the influence of Macpherson's poems on German culture see Koehler (2011).
} 
It was certainly not least German researchers who in the course of the 19th century reopened Celtic peoples' views on their own past (...) In this way, every language expert saw it as an assignment of historical justice to also collect fuel for the other [than Irish] Celtic peoples. If this work yields enough and if the will to live is unbroken, then these peoples themselves will be able to draw the consequences. (Luyken, 1996) ${ }^{10}$

However, the interest in Celtic matters was not only geopolitical.

[In the last decades of the $19^{\text {th }}$ century interest in Gaelic and Celtic culture]

formed part of a general movement throughout Western Europe in matters to do with ethnicity and identity which promoted the "exaltation of the native thing", e.g. language, music, song, folklore, dance etc. and in some places included exaltation of the ethnic grouping, employing terminology such as "race", "blood", "blood and soil" (Blut und Boden), as a fundament to the concept of identity (...). In Germany (...) although (...) most if not all the forgoing took place long before 1933, these concepts 1933-45 fell under the auspices of the Nazis (...). It was in Germany under the Nazis particularly that the "exaltation of the native thing" in all its facets was perfected to fine art. (Broderick, 2019: 3)

This romantic interest, however, was perfectly combined with a political goal.

The nazis took a keen interest in matters Celtic (...) especially the SS-Wissenschafstamt ('Office of Academic Studies') Ahnenerbe ('Heritage of the forefathers') set up in 1935 by Reichsführer-SS Heinrich Himmler (...) and attached to the SS (...). The purpose of Ahnenerbe der SS was evidently to attract specialists in a number of fields of study that could also serve the political interests of the state (...). One such field was devoted to matters Celtic and was headed by prof. dr. Ludwig Mühlhausen (1888-1956), who became professor of Celtic in Berlin [after an earlier appointment in Hamburg] in 1936 on the enforced resignation of his Jewish ${ }^{11}$ predecessor Julius Pokorny (...).” (Broderick, 2019: 5)

The Easter Rising and the subsequent independence of Ireland demonstrated that it was possible for a Celtic country to free itself from the United Kingdom, something which was met with surprise but also with sympathy by the Germans and later the Nazis and showed them how one could be helpful in breaking down the centralist power of traditional opponents. The SS-interest in Celtic matters became focused on destabilizing the UK and France and on fragmenting the control over the Celtic areas of their states (Broderick 2019: 6). The one language - one nation ethnolinguistic ideology turned out to be very fruitful, according to the Nazis, to weaken the national cohesion in the UK and France and ultimately possibly to allow a splinteroff by Celtic speaking areas.

\footnotetext{
${ }^{10}$ For a thorough analysis of the political aspirations of German Celtology between 1900 and 1945 see Lerchenmueller (1997).

${ }^{11}$ Pokorny was baptized Roman Catholic at birth.
} 
The central figure in German Celtic studies of the 1920's till the 1940's was Ludwig Mühlhausen. He was an active member of several Nazi-organisations. With the lawyer and senior Gestapo-official Werner Best (1903-1989), Mühlhausen had been one of the founders of the DGKS, Deutsche Gesellschaft für Keltische Studien 'German Society for Celtic Studies', in 1936. Many Breton nationalists, especially right-wing nationalists, maintained good contacts with the DGKS ${ }^{12}$. In 1942 the DGKS came under direct control of the SS due to an initiative of Mühlhausen, who had become president after Rudolf Thurneysen passed away in 1940.

Mühlhausen combined several positions, just as Leo Weisgerber. From 1940 on they both were active for the Auslandsrundfunkpropganda 'foreign broadcast propaganda. Mühlhausen, who was befriended with the then Irish president Douglas Hyde, was highly respected in Ireland because of his Irish radio broadcasts, which were the first evidence of international recognition for the Irish language (Luyken, 1996).

Best supported the pursuit of Breton autonomy and the Breton language and saw the promotion of Celtic studies as a means to achieve this. In 1942, when he became a high official in the military government of occupied France, wrote that he regarded

the Celtic work under the viewpoints of the long-term political goal of binding the Celtic peoples of Western Europe to the new European order and winning them over for the international coalition formed under German leadership, as vitally important and urgently necessary. (Lerchenmueller, 1997: XII) ${ }^{13}$

Best was smart enough to bring well-trained Celtologists to Brittany for this intended collaboration with Breton groups. It was him who invited Leo Weisgerber, a Celtologist with Germanistic interest ${ }^{14}$, to take on the role of censor (Lerchenmueller, 1997: XII). Weisgerber's activities were much more extensive than just the censorship. Weisgerber initiated the Framm Keltiek Breizh 'Breton Celtic Institute' and he became the leader of Radio Rennes Bretagne for which station he and his Breton friend Roparz Hémon made the first radio broadcasts ever in Breton (Simon, 1982).

Best's tactic to appoint Celticists who had been in contact with Breton nationalists before the war and whom they had influenced in an antidemocratic and natio-

${ }^{12}$ According to Boissou (2002) the DGKS was established on the initiative of the SD, the intelligence agency of the SS, and the Abwehr, the military intelligence service. From the middle of the 1930's there were close contacts between Breton activists and the German intelligence services.

${ }^{13}$ (...) die Keltische Arbeit under den Gesichtspunkten des politischen Fernzieles, die keltische Völker West Europas an die neue europaïsche Ordnung zu binden und für die unter deutscher Führung enstehendes Völkergemeinschaft zu gewinnen, als krigswichtig und dringend notwendig (...).

${ }^{14}$ The then dean of the Bonn Faculty of Arts described Weisgerber in this way in 1952 (Lerchenmueller, 1997: 428). The qualification was meant positively and was given to explain why the appointment of Weisgerber at the chair of Celtic Studies in 1942 had been correct. 
nal-socialist direction worked well. The Parti National Breton 'National Breton Party', which consisted of activists who were highly influenced by the national socialist ideology of leading German Celtic scholars, managed to overshadow completely the whole Breton movement. Consequently, the pursuit of Breton autonomy and the recognition of the Breton language has been discredited for years by this past (Denis, 2002). However, this was not the end of the good relations between German Celticists and Breton nationalists. After the Second World War Weisgerber was instrumental in helping members of the Bezen Perrot SS militia, the Breton SS militia, to acquire false documents in order to escape to Ireland (Simon 1982), where they could meet with Weisgerber's radio colleague from Rennes, the linguist, literary author and fascist Roparz Hémon, who was appointed at the School of Celtic Studies of the Dublin Institute for Advanced Studies (Lerchenmueller, 1997: 429).

Again, the German involvement in the case of the rights of a minority and its language proved not to be a recommendation for a positive attitude towards that minority language after the Second World War. The position of defenders of the rights of minority languages turned out to be seriously weakened by the collaboration of some of the leaders of these groups with the German occupiers during World War II. Especially 'Breton suffered from the legacy of segments of Emsav, 'the Breton movement', joining up with Nazism during the war in hopes of gaining autonomy for Brittany' (Sonntag, 2003: 39).

However, the groups that sought regional autonomy or at least recognition of the rights of their language gradually regrouped. '[B]y the mid-1970s, the level of ethnic conflict in France had reached a scale unequalled - and for most observers unpredicted - in modern French history. In four of the regions, Brittany, Corsica, Occitanie and the Pays Basque, the conflict had escalated to the use of clandestine political violence against the French state and its symbols. The best known of the incidents occurred in 1978 with the bombing of the Palace of Versailles by Breton nationalists' (Jacob and Gordon, 1985: 122-124). Even after the amnesty that President Mitterrand granted to the Breton activists in 1981, releasing 19 prisoners who were sentenced together to 148 years in prison, things did not calm down. In the 1990s, the Armée Révolutionnaire Bretonne, 'Breton Revolutionary Army', ARB, again committed a series of attacks (Bergère, 2006: 106 fn.19). In April 2000 the ARB tried to blow up a post office in Rennes and two McDonald's restaurants in Pornic and Quévert (Sonntag, 2003: 37). ${ }^{15}$

The FNLC, Fronte di Liberazione Naziunale Corsu, 'National Liberation Front of Corsica', which is a separatist organisation that not only fights for linguistic rights

\footnotetext{
${ }^{15}$ For an overview of the dozens of attacks claimed by Breton nationalists between 1966 and 2000 see https://fr.wikipedia.org/wiki/Chronologie_des_attentats_attribu\%C3\%A9s_\%C3\%A0_1\%27Arm\% C3\%A9e_r\%C3\%A9volutionnaire bretonne. For more details about the ARB and its predecessor Front de Libération de la Bretagne, Liberation Frond of Brittany, FLB, see Chartier and Cabon (2005)
} 
but strives for complete autonomy, still commits attacks regularly. It started its violent attacks in $1976^{16}$ and was still active in the summer of $2016 .{ }^{17}$ The FNLC actions also demanded fatalities.

\section{Conclusion}

The cooperation with the German occupation forces did not help the minority movements. Cooperation was seen as collaboration because of the fact that the Nazi's were a foreign and hostile power. That the national government of France and Belgium were also hostile to the case of the linguistic minorities did not play a role in evaluation of this behavior in the post WWII period. The attitude of several of the minority leaders was sentenced as treason. The ignorance of the national governments in the matter of language minorities was not accepted as a mitigating circumstance. In the long run, however, the collaboration of some groups within the minority movements did not harm the cause of minority languages.

After the Second World War a global goal emerged to strengthen human rights. Diversity, including language diversity, is part of that. A series of international treaties is drafted in the second half of the $20^{\text {th }}$ century ${ }^{18}$ which aims to protect the rights of minorities and their culture. Unfortunately, the Belgian and the French government never introduced the European Charter for regional and Minority Languages in their countries. However, the positive effect that the Charter has in the rest of Europe can also be noticed in France and Belgium.

\section{References}

Bergère, M. 2006. "Les usages politiques de la seconde guerre mondiale en Bretagne: Histoire, memoire et identité regionale". In: Crivello, M., Garcia, P. and N. Offenstadt (eds.). Concurrence des Passés. Aix-en-Provence: Presses universitaires de Provence: 103-110.

Boissou, L. 2002. "L'Allemagne et le nationalisme breton. " In: Bougeard. 321-336.

Bougeard, Ch. (ed.) 2002. Bretagne et identités pendant la Seconde Guerre Mondiale. Brest: CRBC-UBO.

\footnotetext{
${ }^{16}$ In the night of 4 May 197626 bombs exploded all over Corsica.

${ }^{17}$ For more details about about the actions of this organization and its history see http://www.unitanaziunale.org/portail/Ribellu_2001.htm

${ }^{18} 1950$ Convention of Human Rights (Council of Europe) 1966 International Covenant on Civil and Political Rights (UN) 1992 European Charter for Regional or Minority Languages (CoE) 1998 Framework Convention for the Protection of National Minorities (CoE) 1999 Declaration for the Rights of Minority People (UN) 2003 Convention for the Safeguarding of the Intangible Cultural Heritage (Unesco)
} 
Broderick, G. 2019. Under the 'Three-legged-swastika': Celtic studies and Celtic revival in the Isle of Man in the era of national socialist/fascist ideology [revised and enlarged version of Broderick 1999 and 2004]. Retrieved 02.05.2019 from https://www.academia.edu/38660261/Under_the Three-Legged-Swastika_Celtic_Studies_and_Celtic_Revival_in_the_Isle_of_Man_in_the_era_of_Na tional_Socialist_Fascist_ideology

Burleigh, M. and W. Wippermann. 1991. The racial state, Germany 1933-1945. Cambridge: Cambridge University Press.

Conway, M. 1994. Degrelle: les années de collaboration: 1940-1944: le rexisme de guerre. Ottignies: Quorum.

De Jonghe, A. 1972. Hitler En het Politieke Lot van België (1940-1944). Antwerpen: De Nederlandsche Boekhandel. Vol. 1

Denis, M. 2002. "Le mouvement breton pendant la guerre; un bilan.". In: Bougeard. 151-166.

De Weever, B. 1994. Greep naar de macht. Vlaams-nationalisme en Nieuwe Orde. Het VNV 1933-1945. Tielt/Lannoo: Perspectief.

Dolderer, W. 2003. "René De Clercq en Duitsland". Retrieved 23.04.2019 from www.rene-declercq.be/RDCweb/eigenpublicaties/RDC en Duitsland 2003.pdf

Frieswijk, J. 1998. "Was er in Friesland een voedingsbodem voor het nationaal-socialisme?" Doopsgezinde Bijdragen, Nieuwe Reeks nummer 24. 263-271.

Jacob, J.E. and D.C. Gordon. 1985. "Language policy in France.” In: Beer, W.R. and J.E. Jacob (eds.). Language policy and national unity. Totowa, N.J.: Rowman and Allanheld. 106-133.

Hamans, C. 2016. "Language policy in the Netherlands." Scripta Neophilologica Posnaniensia XVI. 41-61.

Koehler, A. 2011. Die Helder der Fianna: Goethe und Ossian. Wetzlar: Phantastische Bibliothek.

Lerchenmueller, J. 1997. "Keltischer Sprengstoff”: eine wissenschaftsgeschichtliche Studie über die deutsche Keltologie von 1900 bis 1945. Tübingen: Niemeyer.

Longerich, P. 2010. Holocaust: The Nazi persecution and murder of the Jews. Oxford: Oxford University Press.

Luyken, R. 1996. "Keltologie: Über die Verquickung von Wissenschaften und Nationalsozialismus". Die Zeit 19.07.1996.

Petri, F. 1937. Germanische Volkserbe in Wallonien und Frankreich. Die fränkische Landnahme in Nordfrankreich und den Niederlanden und die Bildung der westlichten Sprachgrenzen. Bonn: Röhrscheid. 2 Vols.

Robins, R.H. and E.M. Uhlenbeck (eds.). 1991. Endangered languages. New York: Berg Publishers.

Simon, G. 1982. "Zündschnur zum Sprengstoff. Leo Weisgerbers Keltologische Forschungen und seine Tätigkeit als Zensurofficier in Rennes während des 2. Weltkriegs." Linguistische Berichte 79: $30-52$.

Sonntag, S.K. 2003. The local politics of global English. Case studies in linguistic globalization. Lanham, Maryland: Lexington Books.

Wood, I. 2013. The modern origins of the Early Middle Ages. Oxford: Oxford University Press.

Zondergeld, G. 1981. "Vlaamse en Friese beweging, een vergelijking." Vlaams Marxistisch Tijdschrift 15.3 retrieved 20.02.2019 from www.marxists.org./nederlands/zondergeld/1981friesland.htm 